\title{
Innovation across Europe: How important are institutional differences?
}

\author{
Natália Barbosa ${ }^{a}$ and Ana Fariaab \\ a Department of Economics, School of Economics and Management, University of Minho, \\ Campus de Gualtar, 4710-057 Braga, Portugal \\ Tel.: +351 253 604542; Fax: +351 253601380 \\ Natália Barbosa: natbar@eeg.uminho.pt \\ Ana Faria: apfaria@eeg.uminho.pt \\ b Corresponding author. Present address (until 25th January 2009): Department of Economics, \\ University of California, 508-1 Evans Hall \#3880, Berkeley, California 94720-3880.
}

\section{October 2008}

\begin{abstract}
The literature on institutions and economic growth has showed that different institutions or policy designs affects productivity growth and international R\&D spillovers. By changing the level of competition and/or affecting resources allocation, institutions can have a significant impact on firms' incentives to innovation. In this paper we test whether the existing institutional variation among European countries explains differences in innovation intensity. Our findings show that stronger regulation in the product market and greater protection of property rights favour innovation activity across Europe, whereas rigidity in the labor market affects negatively firms' incentives to innovate. These results highlight the importance of institutions in shaping innovation, thereby providing a contribution to the design of economic policy.
\end{abstract}

Keywords: Institutions, innovation, European Union.

JEL Classification: O31, O33, O38 


\section{Introduction}

There has been a recent growing interest on the importance of institutions as a means to explain various economic phenomena. For instance, Djankov et al. (2002) and Desai et al. (2003) investigate the impact of institutions on entrepreneurial activity and firm dynamics, Alesina et al. (2005) on investment, Griffith et al. (2007) on unemployment, Coe et al. (2008) on productivity and international R\&D spillovers. These papers find that the institutional environment plays a relevant role in explaining different economic outcomes. In particular, those economies with more regulated markets and higher corruption levels tend to underperform relatively to economies with less restrictive regulation and a better legal environment.

To understand cross-country differences in innovation still is a relevant issue in the literature as it is essential to the design of public policies. Previous evidence shows that these differences are largely explained by differences in national innovation systems (e.g. public investment in R\&D and education) and also by industry-specific characteristics (Furman et al., 2002). Mathieu and Potterie (2008) explored this issue by investigating to what extent differences in innovation performance are more driven by structural factors, such as technological specialization, than by intrinsic national policies. Their results suggest that taking into account the technological specialization of countries drastically reduces the observed macroeconomic differences in relative $R \& D$ efforts. At the same time, some evidence of the impact of institutions on innovation shows that these effects are important to understand cross-country differences in innovation activity.

Nelson's (1993) contribution on national innovation systems provides an important illustration on the relevance of institutional environment in shaping countries' innovation performance and, recently, Nelson (2008) discusses the relationship between institutions and institutional change and technological advance. Besides the national innovation systems approach, some recent literature made an attempt to connect institutions to technological change by focusing on the impact of institutions such as the regulatory framework and the legal system of a country, on innovation. In particular, Bassanini and Ernst (2002) investigated the impact of product and labour market regulation on innovation by using a set of OECD indicators on the regulatory 
framework on a cross-section of 18 OECD countries and 18 manufacturing industries. Their results show an unambiguous negative association between R\&D intensity and non-tariff barriers and inward-oriented economic regulation and a positive association with stronger protection of intellectual property rights. Also, they found a positive association between more flexible labour markets and $R \& D$ intensity. Griffith et al. (2006) explored the impact of product market reform on innovation across industries and EU countries. Their approach is, however, different from Bassanini and Ernst (2002) as they consider the effect of product market reforms on the level of available profits, or rents, to be the key channel through which institutional environment affects firms' incentives to innovate. Griffith's et al. (2006) findings suggest that product market reforms implemented under the European Single Market Programme (SMP) led to an increase in competition which in turn led to an increase in R\&D investment in manufacturing industries. Interestingly, their results also indicate a direct and negative effect of these reforms on R\&D intensity and TFP growth in some high-tech industries with heavy reliance on public procurement. Recently, Kanwar (2007) found evidence showing that the strength of intellectual property protection had a positive impact on business enterprise R\&D expenditure.

In this paper we integrate these literatures by focusing on the specific impact of the institutional environment on innovation, by considering a set of country-specific regulatory and legal indicators and the intensity of innovating firms in the European Union (EU). Our work adds to this literature by highlighting the relevance of national institutions in determining innovation through the use of a richer set of institutional indicators and by focusing our analysis in the EU countries. Two main reasons justify the interest of focusing the analysis on the EU countries. First, different types of institutions or policies maximize growth at different stages of technological development (Aghion, 2005). It is reasonable to expect that (1) different institutions or policy design affects productivity growth differently depending upon a country's or industry's distance to the technological frontier; and (2) a country's distance to the technological frontier affect the type of organizations we observe in this country (e.g. bank versus market finance, vertical integration versus outsourcing). By focusing the analysis on the EU countries we are looking at a relatively homogenous set of countries, thus isolating the country-specific effect of institutions on innovation. The second reason is that over the last decade there has been some convergence in the 
regulatory environment in the EU as a result of the Single Market Program. As such, it is pertinent to investigate to what extent the existing institutional variation between EU countries explains differences in innovation performance. To be able to examine the impact of institutions on innovation, we merge data from the Fourth Community Innovation Survey (CIS4) with data on measures of regulation in the product markets, the labor markets, and the legal system, collected from various sources. Our main findings show that stronger regulation in the product market and greater protection of property rights favours innovation activities across Europe, whereas rigidity in the labor market has a negative impact on innovation.

The remainder of the paper is organized as follows. Section 2 discusses the ways through which institutions can affect innovation. Section 3 describes our data and presents the empirical model. Section 4 describes the econometric approach and discusses the empirical results. Section 5 concludes.

\section{Institutions and innovation}

The term "institutions" has been used in the literature to represent different aspects of economic, legal, political and social activity, which makes difficult to provide a single definition. Following Nelson (2008), who identify institutions as a device to explain "prevalent methods of doing things in contexts where actions and interactions of several parties determine what is achieved" (p. 2), in this paper we focus our attention on a set of administrative and economic practices and policies aimed at regulating the product, labor and capital markets, as well as on the legal and judicial systems, which disclose structures and forces that shape and hold in place the institutional environment affecting innovation activities. As such, our approach to institutions relates closely to the strand that sees institutional change as the rulemaking, or the creation of formal laws that define the playing field, enabling certain groups and retarding the efforts of others (Hwang and Powell, 2005). While these

aspects of regulation do not cover all regulatory dimensions, they include some of the most important to influence innovation. 


\subsection{Product market regulation}

Anti-trust policy is one of the dimensions of product market regulation that is expected to most influence innovation. As anti-trust policy is aimed at reducing market power and market concentration, thus leading to an increase in competition, it will in turn have an impact on firms' incentive to innovate. Although the level of competition has been largely recognized in the literature as one of the main determinants of innovation, economic theory has provided some contradictory results with respect to the relationship between competition and innovation. According to Schumpeter's (1942) seminal contribution, more competition reduces firms' incentives to innovate as the monopolistic rents resulting from innovation are eroded. Nearly 20 years later Arrow (1962) argued that firms in more competitive market have higher incentives to innovate than a monopolist due to the profits replacement effect, i.e., the difference between post-innovation and pre-innovation profits. The possibility of an inverted-U relationship between competition and innovation, however, was first noted by Scherer (1967) when observing a positive relationship between patenting activity and firm size, with a diminishing impact at larger sizes when allowing for nonlinearities. Recently, Dubey and $\mathrm{Wu}$ (2002) showed that innovation is discouraged by too much or too little competition, and occurs only when the industry is of intermediate size. Their argument is that if there are too many firms in the industry, competition will force the price of their current (low-quality) product to be low. Then any firm which innovates will be able to sell the new (high-quality) product only if it is also priced low enough to remain attractive in comparison. But this low price may not even cover the cost of innovation. Thus too much competition can lead to an equilibrium in which no firm innovates. On the other hand, if there are too few firms in the industry enjoying high (e.g. monopolistic or duopolistic) profits, this too can inhibit innovation. For any firm will then opt to innovate only when its profit from the new product exceeds its current profit by at least the cost of innovation. But since current profits are already high, profits from the new product will need to be huge, which may be infeasible on account of bounds on consumers' willingness-to-pay.

Aghion et al. (2005) proposed a model that reconciles the opposite views of too much and too little competition by predicting an inverted-U pattern in the relationship between competition and innovation and showing the opposite effects that competition 
can have on innovation incentives in different types of industries. Whereas traditional industrial organization models of product differentiation and monopolistic competition (Salop, 1977; Dixit and Stiglitz, 1977) only explain the decreasing part of the inverted-U curve by predicting that more intense product market competition discourages innovation by reducing post entry rents, Aghion's et al. (2005) model accounts also for the increasing part of the curve. They follow Arrow's (1962) view in that innovation incentives depend upon the difference between post-innovation and pre-innovation rents of incumbent firms and where competition may increase the incremental profits from innovating, thereby encouraging R\&D investments. Aghion et al. (2005) argue that this is more likely in industries where incumbent firms are operating at similar technological levels and thus engage in what they call "escaping competition" innovation. Consequently, industries that are characterized by "neckand-neck" competition, renovation rents should be especially reduced by product market competition. On the other hand, in industries where innovations are made by laggard firms with already low initial profits, product market competition will mainly affect post innovation rents, and therefore the Schumpeterian effect of competition should dominate. More specifically, when competition is low, a larger equilibrium fraction of industries involve neck-and-neck competing incumbents, so that overall the escape-competition effect is more likely to dominate the Schumpeterian effect. On the other hand, when competition is high, the Schumpeterian effect is more likely to dominate, because a larger fraction of industries in equilibrium have innovation being performed by laggard firms with low initial profits (Aghion et al., 2005, p. 702). Empirical evidence on the impact of increased competition on innovation suggests that it varies across industries (Aghion et al., 2005; Griffith et al., 2006).

Besides the direct impact on competition, stricter anti-trust laws could also lead to smaller average firm size, which, in turn, would imply lower concentration and more competition, all else equal (Kumar et al., 1999). In this case, it could be argued that stricter anti-trust laws may have a negative impact on innovation as firm size is usually positively correlated with innovation. However, the extent to which anti-trust policy is successful in reducing market concentration has also been questioned in the literature (see Mitton, 2008). Furthermore, Maxwell (1998) shows that regulation could reduce firm incentives to innovate in the presence of minimum quality standards. The existence of a minimum quality setting may discourage adoption of quality-cost 
reducing innovations if the innovating firm correctly anticipates that a regulator will raise the minimum standard once an innovation has been discovered. Such regulatory actions reduce the profitability of innovation.

Another important aspect of product market regulation is entry regulation, of which start-up costs are a relevant component. Start-up costs correspond to costs and procedures to comply with government requirements to start a business and most of them are sunk costs. If these costs are high they become a barrier to entry making difficult for entrepreneurs to start a new business, thereby hindering the introduction of innovations. Existing theories of regulation provide different predictions with respect to the impact of these costs on economic activity and who benefits from regulation. The public interest theory (Pigou, 1938) holds that a government must intervene in the market to correct market failures and protect the public interest. Therefore, stricter entry regulation should be associated with socially superior outcomes. The public choice theory has two main strands. One sees regulation as a means of large incumbent firms to maintain their rents (e.g. Stigler, 1971), which is the regulator capture theory. As such, an increase in regulation means less competition, and higher market power for incumbents, preventing new entrants innovation. Another strand argues that regulation is for the benefit of politicians and bureaucrats (e.g. De Soto, 1990). In this case regulation serves no social purpose and is a means for regulators to collect bribes, in any case also raising the costs of entry.

To date, the more compilling empirical evidence on the regulation of entry was provided by Djankov et al. (2002). Based upon a large panel of countries, their results showed that: (1) countries with more regulation of entry have a larger unofficial economy and higher corruption levels; (2) countries with more limited governments, governments more open to competition, and greater political rights have lighter regulation of entry; (3) competition in countries with more regulation is less intense. Antunes and Cavalcanti (2007) provided additional evidence by testing Friedman's et al. (2000) prediction that it is not tax rates per se that induce entrepreneurs to go underground, but bureaucracy and a weak legal system. Their results showed that: (1) both high start-up costs and weak financial contract enforcement explain differences in the size of the shadow economy across countries, with contract enforcement having a larger coefficient; when using independent estimates of enforcement and regulation costs, results indicated that: (2) start-up costs rather than limited contract enforcement 
in financial contracts accounted for the difference in the size of the hidden economy between Mediterranean Europe (Portugal, Spain and Italy) and the United States; (3) in countries with very weak enforcement, credit market imperfection explained roughly $50 \%$ of the difference in the informal industry size, while regulation costs explain the other half.

In brief, entry costs may affect incentives to innovation through two ways. First, these costs may shift resources to the unofficial economy. As firms in the hidden economy have more difficulty in getting credit and attracting highly skilled labor, they will tend to remain small in order to avoid formal-industry minimum-wage requirements (Rauch, 1991). Second, entry costs may reduce potential competition, allowing incumbents to grow or increase their profits, which in turn may or not lead to more innovation. Summing up, product market regulation may affect firms' incentives to innovation in various ways, where, ultimately, the most relevant way is by changing the competition level within the market. However, economic theory does not provide an ambiguous indication to the type of relationship between competition and innovation, therefore the answer to the question of whether more or less competition is more conducive to innovation remains of empirical nature.

\subsection{Labor market regulation}

Labor market regulation can assume various forms such as legislation relating hiring and firing, training, wage rates, policies towards unemployment. As these regulations are aimed at influencing the labor market, it is natural to expect them to impact on innovation also. For example, one can expect that training and education policies will impact positively on innovation by altering the stock of human capital in a given country. Among labor market regulation, employment protection has been pointed out as influencing innovation. Two opposite effects might be expected from employment rigidity. On one hand, rigid hiring and firing regulations increase the bargaining power of unions making more difficult to the firm to adjust wages after the innovation has taken place, or making more difficult for firms to adjust to new technologies as these may require reallocation of staff or downsizing, or even discourage firms from experimenting with new technologies (see Bassanini and Ernst (2002) for a discussion). On the other hand, some argue that stringent layoff regulations are an incentive for 
employers to invest on training thus increasing employees' motivation and productivity (Boone, 2002) or they might decrease the need to maximise current wages, as the employee has a longer time horizon (Acemoglu, 1997). Furthermore, Saint-Paul (2002) showed that countries with rigid labor markets will tend to produce relatively secure goods, at a late stage of their product life cycle, thereby leading to a specialization in "secondary innovations" which improves existing products, rather than "primary innovations" which introduces new products.

Empirical evidence is mixed. Bassinini and Ernst (2002) found that employment protection policies impact on innovation depends on industrial relations regimes (e.g. bargaining arrangements, business associations, business codes of conduct, etc.) and the technology level of the industry concerned. On balance, their results suggest that strict employment protection policies are likely to negatively affect R\&D intensity, especially in high-tech industries of countries where industrial relation systems are relatively decentralized. These differences may reflect differences in the innovation process across industries as well as the role of industrial relations arrangements in affecting how firms satisfy the need for skilled labor to cope with innovation. Koeniger (2005), despite finding evidence that suggested a negative association between dismissal costs and R\&D intensity across countries, also found a positive association within countries over time, which could be explained by a positive innovation effect for incumbent firms. Recently, Falk et al. (2008) provided evidence on the impact of employment protection policy on contract enforcement behavior by focusing on dismissal barriers, and bonus pay. Dismissal barriers were shown to have a strong negative impact on worker performance, and market efficiency, by interfering with firms' use of firing threat as an incentive device. Furthermore, dismissal barriers also distort the dynamics of worker effort levels over time, cause firms to rely more on the spot market for labor, and create a distribution of relationship lengths in the market that is more extreme, with more very short and more very long relationships. The introduction of a bonus pay option dramatically changes the market outcome. Firms are observed to substitute bonus pay for threat of firing as an incentive device, almost entirely offsetting the negative incentive and efficiency effects of dismissal barriers. Nevertheless, contract enforcement behavior remains fundamentally changed, because the option to pay bonuses causes firms to rely less on long-term relationships. As these results show that market outcomes are the result of a complex interplay between 
contract enforcement policies and the institutions in which they are embedded, they also strongly suggest that rigidity in the labor market has a negative impact on innovation as it brings additional constraints to firms.

\subsection{Legal system and intellectual property protection}

Another institution that has been found relevant in determining innovation is the legal system and, in particular, the strength of intellectual property rights (IPRs) of a country. There is a vast literature examining the costs and benefits of IPRs protection and their effects on innovation and growth (see Hall (2007) for a survey on patent effectiveness in encouraging innovation and current controversies in patent policy). In endogenous growth models (Romer, 1990; Aghion and Howitt, 1992) the protection of IPRs is essential in order to protect the rents of innovators against imitation, therefore to guarantee the return to innovation. Eicher and Garci-Peñalosa (2008) went a step further by explaining endogenous differences in intellectual property rights across countries via private incentives to invest in property rights with multiple equilibria. Their model allows identifying an institutional threshold of best practices in terms of intellectual property protection, where weak investment in IPR quality eventually leads to large-scale misappropriation of the returns to innovation and a fall in R\&D activity as the economy reverts to the no-growth. Studies at the industry-and firm level also provide arguments along the same line where an effective legal system and property rights protection are expected to have a positive impact on innovation because it encourages new economic activity and foster the growth of new firms and business by allowing a reduction in idiosyncratic risk (Laeven and Woodruff, 2007) and the formation of larger firms (Rajan and Zingales, 1998).

Empirical evidence on the impact of the legal system and property rights on innovation is still scarce. Nonetheless, the existing empirical evidence shows a positive relationship between the quality of the legal system and strenght of property rights and innovation (Bassanini and Ernst, 2002; Kanwar, 2007).A vast number of studies argue that stronger IPRs are an incentive to innovation, even though some defend that the patent system could delay innovation (Bessen, 2005). Furthermore, as noted by Hall (2007): (1) strengthening a patent system (lengthening the patent term, broadening subject matter coverage or available scope, improving enforcement) unambiguously 
results in an increase in patenting and also in the use of patents as a tool of firm strategy; (2) an increase in innovation due to patents is likely to be centered in some industries, namely pharmaceutical, biotechnology, medical instrument industries, and possibly specialty chemicals. Given this evidence and the previous discussion we expect more stringent legal systems to have a positive effect on innovation particularly on industries that use patents as their appropriation strategy.

\subsection{Capital market regulation}

Capital markets imperfections might arise due to adverse selection and moral hazard problems, which make external finance expensive or even unavailable to the firm. Financial constraints are one of the main reasons that prevent new firms from attaining their optimal initial size (Cabral and Mata, 2003) and might be particularly relevant in high-tech industries. According to Carpenter and Petersen (2002) this is so because returns from high-tech investment are highly uncertain, therefore $R \& D$ projects have a low probability of financial success. Also, substantial information asymmetries are likely to exist between firms and potential investors. These arise because high-tech investments are difficult to evaluate and frequently embody new knowledge, consequently, insiders will have much better information than outsiders about the prospects of the firm's investments, and due to appropriation problems firms limit the amount of information they provide to suppliers of funds. Finally, high-tech investments often have limited collateral value because most of $R \& D$ investment is predominantly salary payments, which has little salvage value in the event of failure, and physical investments designed to embody R\&D results are likely to be firm specific.

Start-ups may also have more difficulty to access credit as liquidity constraints become more severe as firm size decreases. Stiglitz and Weiss (1981) observed that the market for credit is exceptional in that the price of the good - the rate of interest, is not necessarily at a level that equilibrates the market. They attribute this to the fact that interest rates influence not only demand for capital but also the risk inherent in different classes of borrowers. As the interest rate rises, so does the riskiness of

borrowers, leading suppliers of capital to rationally decide to limit the quantity of loans they make at a particular of interest rate. Petersen and Rajan (1992) noted that 
potential lenders have little information on the managerial capabilities or investment opportunities of such firms and are unlikely to be able to screen out poor credit risks or to have control over a borrower's investments. There is a growing empirical literature investigating in what extent capital decisions at start-up have important implications for firm performance (Bottazzi and Da Rin, 2002; Cassar, 2004; Audrestch and Elston, 2006). Whereas venture capital is found to be important to firm creation, some studies fail to show a positive impact on their growth (e.g. Bottazzi and Da Rin, 2002). Indeed, recent evidence (Becker and Hellmann, 2000) seems to support the results found by (Cressy, 1996) where the lack of human capital is more important than financial constraints to start-ups'survival.

Given the importance of capital markets, such regulations such as legal investor protection and credit bureaus, are also expected to have a significant impact on incumbents' performance as well as on start-ups. According to Cabral and Mata (2003) an increase in financial development will reduce concentration. Davis and Henrekson (1997) argue that regulations restricting capital access favor larger established firms at the expense of smaller entrants. On the other hand, Kumar et al. (1999) argue that financial development can have two effects on the firm size distribution: it promotes growth of existing firms, but also promotes entry of new firms (as shown in Rajan and Zingales, 1998). Mitton (2008) argues that while the effect of financial development on average firm size is ambiguous, it should unambiguously reduce concentration, as long as the availability of finance promotes growth equally across the size distribution. Based on cross-country determinants of private credit Djankov et al. (2007) found that both creditor protection through the legal system and information sharing institutions are associated with higher ratios of private credit to GDP. They also found that credit rises after improvements in creditor rights and in information sharing.

The impact of credit market regulation on innovation is also difficult to pin down, as the literature offers different arguments. On one hand, better financial development and information sharing seems to be favorable to new entrants and/or small firms, particularly in industries with more technology based start-ups, which in turn may lead to an increase in competition. On the other hand, some credit regulations may be more favorable to incumbent firms, thus allowing them to grow, and, possibly, leading to an increase in concentration. 
The previous discussion on ways through which institutions can affect innovation has made clear that it is difficult to establish at the theoretical level the effects that product, labor and capital markets regulation can have on innovation. A similar problem has been noted by Alesina et al. (2005) on the relationship between regulation and investment and by Mitton (2008) on the relationship between regulation and concentration. As regulation will change competition levels, its effects on innovation will most likely vary across industries as firms'incentives to innovate largely depend upon the competitive environment and the characteristics of technology. In the end, the answer has to be found empirically.

\section{Data, empirical model and variables}

\subsection{Data}

Our data came from different sources. Our main data source is the Fourth Community Innovation Survey (CIS4) which covers the years 2002 to 2004 and most EU countries. The main advantage of using these data is that the definitions of variables and the methodology used in collecting the data are consistent across countries. Our sample is restricted to manufacturing industry and due to data availability the countries included in the final sample are: Belgium, Denmark, Germany, Greece, France, Italy, Portugal, The Netherlands, Spain and Sweden. Access to CIS4 firm level data is subject to strong restrictions, thus we only have access to 2-digit level NACE (Nomenclature Génerale des Activités Économiques dans les Communautés Européennes) classification data. From the CIS4 we collected data on employment, R\&D expenses and the number of firms that introduced innovations, either in product or process, in 2004.

This data was then merged with data on countries' institutional environment, which were collected from various sources, namely the Doing Business Database, Governance Indicators Database, both from World Bank, and from the OECD Indicators of Product Market Regulation Database. Both World Bank and OECD have produced several indicators aimed at measuring the institutional and regulatory environments of countries that in some cases are equivalent. The choice of each indicator was determined by both content and data availability, thus whenever possible we chose indicators that did not overlap in terms of content. In particular, we 
consider synthetic indicators of the stringency of regulations in the labor and product market regulation, regulation of entry, the degree of enforcement of laws and regulations, and the degree of quality of information in capital markets. We supplemented our data with patent data from OECD Patent and R\&D Databases, from 1991 to 2002, and with gross domestic production (GDP) and population data collected from OECD Statistics.

\subsection{Empirical model and variables}

In order to investigate the effect of country-level variation in institutions on innovation in Europe we rely on a cross-section of 20 2-digit manufacturing industries ${ }^{1}$ in 10 countries of the EU. In this way we control for industrial heterogeneity in a context where technologies are relatively homogenous yet there is variation in institutional regimes at the country level. Our estimation equation is thus specified by:

$$
\operatorname{Innov}_{\mathrm{ij}}=\mathbf{I N S T}_{\mathrm{j}} \beta+\boldsymbol{\mu}_{\mathrm{ij}} \alpha+\mathbf{\eta}_{\mathrm{j}} \gamma+\mathrm{e}_{\mathrm{ij}}
$$

where $\operatorname{Innov}_{i j}$ is the proportion of innovating firms in industry $i$ of country $j, \mathbf{I N S T}_{j}$ is a vector of indicators of country-level institutions that vary across countries, $\boldsymbol{\mu}_{i j}$ is a vector of industry-specific variables that vary across countries, $\mathbf{\eta}_{j}$ is a vector of country- specific characteristics and $\mathrm{e}_{i j}$ is a disturbance term capturing unobservable variables affecting innovation activities. $\beta, \alpha$, and $\gamma$ are the conformable vectors of unknown parameters.

${ }^{1}$ The industries included are: 15 (Food products and beverages), 16 (Tobacco), 17 (Textiles), 18 (Wearing apparel), 19 (Tanning, dressing of leather; manufacture of luggage), 20 (Wood and of products of wood and cork, except furniture, articles of straw and plaiting materials), 21 (Pulp, paper and paper products), 22 (Publishing, printing and reproduction of recorded media), 24 (Chemicals and chemical products), 25 (Rubber and plastic products), 26 (Non-metallic mineral products), 27 (Basic metals), 28 (Fabricated metal products, except machinery and equipment), 29 (Machinery and equipment n.e.c.), 31 (Electrical machinery and apparatus n.e.c.), 32 (Radio, television and communication equipment and apparatus), 33 (Medical, precision and optical instruments, watches and clocks), 34 (Motor vehicles, trailers and semi-trailers), 35 (Other transport equipment), 36 (Furniture; manufacturing n.e.c.). 
The parameters of interest are the $\beta$ coefficients on the institutional indicators. Regulations and laws affecting the quality of anti-trust policy and regulation, financial institutions, reliability of legal and judicial system will affect markets for goods and services as they will impact on the level of competition and the way resources are allocated. Thereby, these will impact on incentives to innovation. As indicators for product market regulation we include ERegul, a summary index of economic regulation that captures aspects of inward and outward-oriented economic regulation, such as state control, legal barriers to entry, price controls, tariff and non-tariff trade barriers, and ARegul, a summary index of administrative regulation, which captures administrative barriers on start-ups, features of the licensing and permit system, communication and simplification of rules and procedures. Both indicators measure on a scale from 0 to 6 (from least to most restrictive) restrictions on competition and private governance and were collected from OECD Product Market Regulation Indicators Database. The last indicator of product market regulation is the variable Entry, which measures the cost of entry by the ratio of cost of starting new business to GDP. This indicator was collected from the Doing Business Database of the World Bank Group.

Labor market regulation is measured by the indicator Employment, which is an employment rigidity index and represents the difficulty for firms of adjusting the labor force. The index deals with three broad areas of labor regulation, namely employment laws, collective relations laws, and social security laws. The index measures the strictness of protection against alternative employment contracts, the cost of increasing working hours, the economic cost of firing workers, and restrictions on employers for firing workers, whether individually or collectively. Higher values correspond to more extensive legal protection of workers. This indicator was collected from the Doing Business Database, The World Bank Group.

The variable Law is an indicator of the efficiency of the legal and judicial system in resolving legal disputes. It measures the extent to which agents have confidence in and abide by the rules of society, and in particular the quality of contract enforcement, protection of property rights, the police, and the courts, as well as the likelihood of crime and violence. The indicator is constructed to have a mean of zero and a standard deviation of one in each period. Actual scores range from approximately -2.5 to 2.5 , 
with higher scores corresponding to better outcomes. The source of this indicator was the Governance Indicators Database, The World Bank Group.

Our indicator of capital markets' regulation is Credit, which is a credit information index. The credit information index measures rules affecting the scope, accessibility and quality of credit information available through either public or private credit registries. The index ranges from 0 to 6 , with higher values indicating the availability of more credit information, from either a public registry or a private bureau, to facilitate lending decisions. This index was collected from the Doing Business Database, The World Bank Group.

Other control variables included in the regression are the following. At the country-level, the variable GDP, measures gross domestic product by capita, where we expect a positive impact of this variable on innovation by providing firms with a larger market and better infrastructures. The variable Patent measures the national knowledge stock and is proxied by the growth rate in triadic patent families over the period 1991-2000. Patent stock controls for the past average innovation engagement of each country, where we expect that countries with past innovative behavior will continue this strategy. At the industry-level, we include Size, measured by the industry (log) total turnover in 2002. Industry-specific capabilities in terms of innovation will also depend on how much is invested on $R \& D$. The variable $R \mathcal{E} D$ is the industry $i$ of country $j$ total expenditure in R\&D. Finally, we include industry dummies in order to control for differences in technological regimes. We further use Pavitt (1984) taxonomy ${ }^{2}$ to classify the industries. According to this taxonomy, four types of industries are identified, namely scale-intensive, science based, specialized suppliers and supplier dominated. The variable Scale intensive indicates industries where firms are mostly operating in bulk materials and assembly. Their internal sources of technology are production engineering and R\&D departments. External sources of technology include mainly interactive learning with specialized suppliers, but also inputs from science-based firms are of some importance. The variable Science based

\footnotetext{
2 This taxonomy classified firms, according to principal activity, based upon the sources of technology, the nature of users' needs, and means of appropriation, which then allows for a industry-level classification.
} 
indicates the science based industries, which are mainly associated with the chemical and electronic industries and their main internal sources of technology are internal $R \& D$ and production engineering. Important external sources of technology include universities, but also specialized suppliers. The variable Specialized suppliers indicates the industries that are characterized by small firms that are producers of production equipment and control instrumentation. Their main internal sources are primarily design and development. External sources are users (science based and scale-intensive firms). The variable Supplier dominated indicates those industries that are characterized by small firms whose technology comes from suppliers of equipment and material. We expect the specialized suppliers and science based industries to have higher intensity of innovative firms than the supplier dominated and scale intensive industries. This taxonomy main limitation, as any other taxonomy, relates to the fact that these boundaries are not always straightforward. Nevertheless, it still is an important yardstick to describe differences in technological regimes across industries. Table 1 lists the definition of each variable used in the empirical analysis, exact source and time period, and the expected impact on innovation activity according to previous discussion on Section 2.

\section{Insert Table 1 here}

Table 2 reports some descriptive statistics of the dependent variable and regressors we use in the empirical analysis. Part I of the table reports some summary statistics, whereas Part II reports correlation coefficients among selected variables. The data listed in Table 2 shows that differences in innovation, measured by the proportion of innovative firms, across Europe are quite significant as shown by the large standard deviation of the variable Innov. Another interesting feature is that European countries differ more with respect to their R\&D expenditures than in GDP per capita. The data also shows some variation with respect to institutions across EU countries. In particular, EU countries seem to differ most in employment regulation, followed by regulation on capital markets, and less with respect to the cost of entry. The correlation coefficients show that GDP per capita has a negative correlation with heavier regulatory environments (ERegul, ARegul, Entry) as well as with more rigid labor markets, and a positive correlation with better legal and judicial systems and more information sharing (Law and Credit). The correlation coefficients between institutional 
factors are not high, except for the correlation between Law and ERegul (-0.826) and Law and Entry (0.832), which means that overall there is not an overlap in the measurement of variables.

Insert Table 2 here

\section{Econometric model and results}

\subsection{Econometric model}

The nature of the dependent variable, the proportion of innovating firms in industry $i$ of country $j$, shall suggest us to apply the econometric method proposed by Papke and Wooldridge (1996). Their main assumption applied to (1) will be that, for all $i$ and $j$

$$
\mathrm{E}\left(\operatorname{Innov}_{\mathrm{ij}} \mid \mathbf{I N S T}_{\mathbf{j}}, \boldsymbol{\mu}_{\mathrm{ij}}, \mathbf{n}_{\mathbf{j}}\right)=\mathrm{G}\left(\mathbf{I N S T}_{\mathbf{j}} \beta+\boldsymbol{\mu}_{\mathrm{ij}} \alpha+\mathbf{\eta}_{\mathbf{j}} \gamma\right)
$$

where $G($.$) is a known cumulative distribution satisfying 0<G(z)<1$ for all $z \in R$. This ensures that the predicted values of the proportion of innovating firms in industry $i$ of country $j$ lie in the interval $(0,1)$. The two most common choice for $G($.$) are the logistic$ distribution and the standard normal cumulative function. However, based on Gourieroux et al. (1984) and McCullagh and Nelder (1989), Papke and Wooldridge (1996) propose to estimate the unknown parameters by a quasi-likelihood method, which only requires the validity of the mean function (see, equation (2)) and the choice of a cumulative distribution that is a member of the linear exponential family, regardless of if it is or not the true distribution. If these two conditions hold, then the quasi-maximum likelihood estimator (QMLE) of $\beta, \alpha$, and $\gamma$ provide consistent estimates of the unknown parameters.

The dependent variable, Innov $i j$, is, however, a special case as it is a proportion of a count variable - number of innovating firms - from a group of known size - total number of observed firms. The Papke-Wooldrigde method ignores the information on group size. Although they have argue that, under the imposed assumptions, "the method ... need not be less efficient than methods that used information on group size" (p. 621), we use a QMLE estimator that takes into account the nature of the dependent variable and allow us to control for group size. Thus, the QMLE Poisson 
estimator, using group size as the exposure control, follows as the natural choice from the above arguments. The empirical model is then defined as

$$
\mathrm{E}\left(\operatorname{Innov}_{\mathrm{ij}} \mid \mathbf{I N S T}_{\mathbf{j}}, \boldsymbol{\mu}_{\mathrm{ij}}, \mathbf{n}_{\mathbf{j}}\right)=\log i n n_{\mathrm{ij}}=\exp \left(\mathbf{I N S T}_{\mathbf{j}} \beta+\boldsymbol{\mu}_{\mathrm{ij}} \alpha+\mathbf{n}_{\mathbf{j}} \gamma+\log n_{\mathrm{ij}}\right)
$$

where $i n n_{\mathrm{ij}}$ is the number of innovating firms in industry $i$ of country $j$ and $n_{\mathrm{ij}}$ the total number of observed firms in industry $i$ of country $j$ - the measure of group size. The advantage of this alternative approach is to use information on group size and allow us to discriminate between equal values of the proportion of innovating firms. Further, it maintains the computational simplicity of the Papke-Wooldrige method and estimates have a similar interpretation.

\subsection{Results}

Table 3 reports coefficient estimates from regressions of the intensity of innovative firms of manufacturing industries on country-level measures of institutional factors as well as other country-and industry-specific effects. We estimate three models. The most restricted model only includes the institutional indicators and country-and industry specific economic variables that are most expected to influence innovation. The intermediate model further controls for industry-specific technological regimes and the extended model contains interaction effects between institutions and industryspecific characteristics. In all regressions the institutional indicators are lagged one year to avoid a potential endogeneity problem. ${ }^{3}$

From model (1) in Table 3 we can see that institutional variation explains differences in the intensity of innovative firms across European countries along with

3 Other authors have addressed the possibility that regulation itself may respond to such industry specific technological opportunities, generating an endogeneity problem for the regulation variable in models that do not control for such shocks. For example, Alesina et al. (2005) have addressed this in the context of technological change associated with cellular phones and wireless technology, showing that a new market structure in the telecommunication industry may thus have lent impetus to deregulation. As our data is a cross-section and our institutional indicators are lagged one year, the endogeneity problem is not likely to affect our results. 
income level, patent stock, R\&D expenditure and industry size with almost all institutional indicators being significant at the $1 \%$ or $5 \%$ level. Furthermore, these results are robust to the various model specifications, where the only changes in significance are in the coefficients of Entry and Credit. The institution that has the largest effect on the intensity of innovative firms is economic regulation (ERegul), an indicator for product market regulation. The positive value of its estimate means that more regulation is leading to more innovation. A similar effect is observed on the variable ARegul, a proxy for administrative regulation. Also, estimates show that tougher entry regulation (Entry), proxied here by higher entry costs, have a positive effect on innovation. These findings are consistent with the Schumpeterian view that less competition favors firms' incentives to innovation as well as with the public choice theory strand that argues that regulation is designed to protect incumbent firms' interests. These results could also be interpreted as being a consequence of the fact that our final sample is biased towards French civil law countries, which have the tradition of regulating entry of new firms, dispute resolution in courts, and other activities more heavily than do common law countries (Ardagna and Lusardi, 2008; La Porta et al. 1998, Djankov et al. 2002).

Labor market regulation and protection of property rights are also important institutions in determining innovation in European countries. That is, the variable Employment, a proxy for labor markets rigidity, has a negative and significant effect on innovation, a finding that has important policy implications, and Law, a proxy for the quality of the judicial system and protection of property rights, has a positive effect on innovation. The magnitude of the coefficients implies that, ceteris paribus, in countries that have a rigid labor market the intensity of innovation decreases 1.89 for a unit increase in the indicator of employment rigidity and, on the other hand, innovation intensity increases 1.18 for a unit increase in the indicator for the quality of the judicial system and protection of property rights. These results are also consistent with previous empirical evidence (Bassanini and Ernst, 2002; Kanwar, 2007). Finally, the capital markets' indicator, Credit, although not significant in the first model, is significant at the $10 \%$ level on the last model. We discuss its impact on innovation later.

The country-level results of model (1) demonstrate the average correlation between institutions and other relevant innovation determinants but it does not take into account structural differences across industries. Model (2) controls for these differences 
by including a set of dummy variables that classify industries according to Pavitt's taxonomy as discussed in Section 3.2. The omitted group is the supplier dominated industries, which are representative of the more traditional industries and less intensive innovative industries. All the coefficients estimates of the dummy variables have a positive value and are highly significant and, as expected, the science based industries have the largest coefficient, followed by the specialized suppliers and scale intensive industries, respectively.

As discussed in Section 2, the literature suggests that the effects of institutions on innovation may differ across different types of industries. To test for these effects, we interact the country-level institutional factors with the industry dummies. Since product market regulation is aimed to influence competition, its effects on firms' incentives to innovation may vary across different industries because these incentives largely depend on the competitive environment. Previous evidence found a negative effect of the increase in competition on high-tech industries (Griffith et al., 2006) and that the effect of competition on innovation depends on whether the technology level among competitors is identical or not (Aghion et al., 2005). Furthermore, regulation may influence the intensity of innovative firms in a given industry as it may also influence the average firm size. However, the literature does not provide a clear indication of the direction of the effect of regulation on firm size, and the empirical evidence on the relationship between firm size and innovation is ambiguous. As such, we interact our three indicators of product market regulation with all industry dummies and let the data tell us how the institutions' interaction with industry characteristics impact on innovation. We further include interaction terms between the other three institutional indicators and the science based and specialized industries dummy variables, which are the most innovation intensive industries. Although, employment rigidity seems to have an overall negative effect on innovation, its effect may differ across industries with different technological regimes. Specifically, if the competencies required to implement innovations are rarely available inside the firm, the adjustment cost imposed by hiring and firing restrictions will be high. Conversely, if the competencies required to carry on the innovation process are more easily developed in-house, these adjustment costs will be relatively low (Bassanini and Ernst, 2002). Also, the protection of property rights will be more relevant in industries in which the main appropriation strategy is through patents (e.g. pharmaceuticals) versus 
a strategy based on secrecy, more common in process innovation. Finally, the need to use the capital market might be stronger in industries characterized by short product cycles where it is more common to find technology based start-ups (e.g. biotechnology).

Model (3) reports estimates of the interaction effects between institutions and industries, where the estimates of interest are those of the coefficients of the interaction terms, which indicate the magnitude and significance of the differential effects of the institutional factors across different types of industries. The evidence found corroborates the idea that institutions affect the incentives to innovation differently across industries as the industry dummies loose statistical significance whereas some interaction retain are statistically significant. Among product market regulation indicators, results show that entry costs have a positive and significant impact on all industries, which seems to corroborate public choice theory and Stigler's argument, and that economic regulation has a stronger impact on specialized suppliers industries. Also, law enforcement and property rights protection has a stronger effect on specialized suppliers, whereas employment protection is more relevant to science based industries. The negative estimate for the variable Credit means that the availability of more credit information is having a negative effect on innovation, which is particularly true on the science based industries. This negative effect can be interpreted as the result of an increase in competition faced by incumbents as small firms and new entrants benefit from the increase in information sharing. The fact that this effect is stronger in the science based industries supports this interpretation, since technology based start-ups are more common among these industries.

Finally, the estimates of the other explanatory variables are all very significant, except for the coefficient of the variable $R \mathcal{E} D$, which looses statistical significance when we control for industry-specific effects. It is worth noting that a country's knowledge stock has the strongest effect on innovation, followed by the country's income. At the industry-level, the negative sign of the coefficient of Size means that innovation is not driven by the importance of the industry, measured by its total turnover. On the other hand, the non-significance of the coefficient of the variable $R \mathcal{E} D$, after we control for industry-specific effects, implies that differences in the technological regime are more important to explain differences in the intensity of innovation than R\&D expenditures. 


\section{Conclusions}

In this paper we tested whether institutional variation is important to explain differences in the intensity of innovation across industries in EU countries. Our focus was on a set of regulatory practices and policies that are aimed at regulating labor, product and capital markets, as well as on the legal and judicial system of the countries. Since theoretical contributions do not provide a clear cut prediction on the relationship between institutions and innovation, ultimately the answer has to come from the data. Our empirical results show that institutional variation is relevant to explain differences in the intensity of innovation in the manufacturing industries of EU countries. Furthermore, results are robust after controlling for industry-and countryspecific characteristics. We found a positive effect of more product market regulation on innovation, which seems to corroborate the public choice theory argument that more regulation is a means of large incumbent firms to maintain their rents. A similar argument seems to explain the negative impact of capital market regulation, measured by the availability of more credit information, particularly in the science based industries. The evidence found also suggests that more rigid labor market regulation has a negative effect, whereas stricter protection of property rights has a positive impact on firm's incentive to innovation, which corroborates previous empirical evidence. Finally, our findings confirm that institutions have different impacts across industries and highlight the importance of distinguishing between these effects on policy design.

Acknowledgements: The authors wish to thank the Portuguese Foundation for Science and Technology (FCT) for funding the project "Firms' heterogeneous capabilities and industrial dynamics" under research grant POCI/EGE/56937/2004 (partially funded by FEDER).

\section{References}

Acemoglu, D., 1997. Training and Innovation in an Imperfect Labour Market. Review of Economic Studies 64, 445-464. 
Aghion, P., 2005. Growth and Institutions. Empirica 32, 3-18.

Aghion, P., Bloom, N., Blundell, R., Griffith, R., Howitt, P., 2005. Competition and Innovation: An Inverted-U Relationship. The Quarterly Journal of Economics 120 (2), 701-728.

Aghion, P., Howitt, P., 1992. A Model of Growth through Creative Destruction. Econometrica LX, 323-351.

Alesina, A., Ardagna, S., Nicoletti, G., Schiantare, F., 2005. Regulation and Investment. Journal of the European Economic Association 3 (4), 791-825.

Antunes, A. R., Cavalcanti, T. V., 2007. Start up costs, limited enforcement, and the hidden economy. European Economic Review 51, 203-224.

Ardagna, S., Lusardi, A., 2008. Explaining International Differences in Eentrepreneurship: The Role of Individual Characteristics and Regulatory Constraints. NBER Working Paper No. 14012.

Arrow, K., 1962. Economic welfare and the allocation of resources for invention, in: Stephan, P., Audrestch, D. (Eds.), The Economics of Science and Innovation, Vol. 1. Edward Elgar, Cheltham, pp. 61-77.

Audrestch, D., Elston, J., 2006. Can institutional change impact high-technology firm growth?: Evidence from Germany's Neuer Markt. Journal Productivity Analysis 25 (12), 9-23.

Bassanini, A., Ernst, E., 2002. Labour Market Institutions, Product Market Regulation, and Innovation: Cross-Country Evidence. OECD Department of Economics Working Paper No.316.

Becker, R., Hellmann, T., 2000. The genesis of venture capital: Lessons from the German. mimeo (http:/ / faculty-gsb.stanford.edu/hellmann).

Bessen, J., 2005. Patents and the diffusion of technical information. Economics Letters $86,125-128$. 
Boone, J., 2000. Competitive pressure: the effects on investments in product and process innovation. RAND Journal of Economics 31 (3), 549-569.

Botero, J., Djankov, S., La Porta, R., Lopez-de-Silanes, F., Shleifer, A., 2004. The Regulation of Labor. Quarterly Journal of Economics 119 (4), 1339-82.

Bottazzi, L., Da-Rin, M., 2002. Venture capital in Europe and the financing of innovative companies. Economic Policy April, 231-269.

Cabral, L., Mata, J., 2003. On the evolution of the firm size distribution: facts and theory. The American Economic Review 93, 1075-1090.

Carpenter, Petersen, B., 2002. Capital Market Imperfections, High-Tech Investment, and New Equity Financing. The Economic Journal 112, F54-F72.

Cassar, G., 2004. The financing of business start-ups. Journal of Business Venturing 19, 261-283.

Coe, D., Helpman, E., Hoffmaister, A., 2008. International R\&D Spillovers and Institutions. NBER Working Paper No. 14069.

Conway, P., Janod, V., Nicoletti, G. (2005). Product Market Regulation in OECD Countries, 1998 to 2003. OECD Economics Department Working Paper No. 419.

Cressy, R. (1996). Are Business Startups Debt-Rationed?. The Economic Journal 106 (438), 1253- 1270.

Davis, S., Henrekson, M., 1997. Explaining national differences in the size and industry distribution of employment. NBER Working Paper No. 6246.

De Soto, H., 1989. The Other Path, Harper and Row, New York.

Desai, M., Gompers, P., Lerner, J., 2003. Institutions, capital constraints and entrepreneurial dynamics: evidence from Europe. NBER Working Paper No. 10165.

Dixit, A., Stiglitz, J., 1977. Monopolistic Competition and Optimum Product Diversity. The American Economic Review LXVII, 297-308. 
Djankov, S., La Porta, R., Lopez-de-Silanes, F., SchleiferA., 2002. The Regulation of Entry. The Quarterly Journal of Economics 67 (1), 1-37.

Djankov, S., McLiesh, C., Shleifer, A., 2007. Private Credit in 129 Countries. Journal of Financial Economics 84 (2), 299-329.

Dubey, P., Wu, C.-W., 2002. When less competition induces more product innovation. Economics Letters 74, 309-312.

Eicher, T., García-Peñalosa, C., 2008. Endogenous strength of intellectual property rights: Implications for economic development and growth. European Economic Review 52, 237-258.

Falk, A., Huffman, D., MacLeod, W. B., 2008. Institutions and Contract Enforcement. NBER Working Paper No.13961.

Friedman, E., Johnson, S., Kaufman, D., Zoido-Lobaton, P., 2000. Dodging the grabbing hand: The determinants of unofficial activity in 69 countries. Journal of Public Economics 76, 459-493.

Furman, J., Porter, M., Stern, S., 2002. The determinants of national innovative capacity. Research Policy, 31, 899-933.

Gourieroux, C., Monfort, A., Trognon, A., 1984. Pseudo-maximum likelihood methods: theory. Econometrica 52, 681-700.

Griffith, R., Harrison, R., Simpson, H., 2006. Product Market Reform and Innovation in the EU. CEPR Discussion Paper No. 5849.

Griffith, R., Harrison, R., Macartney, G., 2007. Product Market Reforms, Labour Market Institutions and Unemployment. Economic Journal 117 (519), C142-66.

Hall, B., 2007. Patents and Patent Policy. Oxford Review of Economic Policy, 23 (4), 568-587. 
Hwang, H., Powell, W. W., 2005. Institutions and entrepreneurship, in: Alvarez, S.A., Agarwal, R., Sorenson (Eds.), Handbook of Entrepreneurship Research: Interdisciplinary Perspectives, Springer, New York, pp. 179-210.

Kanwar, S. (2007). Business enterprise $R \& D$, technological change and intellectual property protection. Economics Letters 96, 120-126.

Kaufmann, D., Kraay, A., Mastruzzi, M., 2003. Governance matters III: governance indicators for 1996-2002. World Bank Policy Research Working Paper No. 3106.

Koeniger, W., 2005. Dismissal costs and innovation. Economics Letters 88, 79-84.

Kumar, K., Rajan, R., Zingales, L., 1999. What determines firm size?. NBER Working Paper No. 7208.

La Porta, R., Lopez-de-Silanes, F., Shleifer, A., Vishny, R. W., 1998. Law and Finance. Journal of Political Economy 106, 1113-1155.

Laeven, L., Woodruff, C., 2007. The quality of the legal system, firm ownership, and firm size. The Review of Economics and Statistics 89, 601-614.

Mathieu, A., Potterie, B., 2008. A note on the drivers of R\&D intensity. CEPR Working Paper No.6684.

Maxwell, J. W., 1998. Minimum quality standards as a barrier to innovation. Economics Letters $58,355-360$.

McCulagh, P. Nelder, J. A., 1989. Generalized Linear Models, second ed., Chapman and Hall, New York.

Mitton, T., 2008. Institutions and concentration. Journal of Development Economics 86, 367-394.

Nelson, R., 1993. National Innovation Systems: A Comparative Analysis, Oxford University Press, Oxford. 
Nelson, R., 2008. What enables rapid economic progress: What are the needed institutions?. Research Policy 37, 1-11.

OECD/Eurostat, 1997. Proposed Guidelines for Collecting and Interpreting Technological Innovation Data - Oslo Manual, OECD, Paris.

Papke, L., Wooldridge, J., 1996. Econometric methods for fractional responses variables with an application to 401(k) plan participation rates. Journal of Applied Econometrics $11,619-632$

Petersen, M., Rajan, R., 1992. The benefits of firm-creditor relationships: evidence from small business data. University of Chicago, Working Paper No. 362.

Pigou, A. C., 1938. The Economics of Welfare, fourth ed., Macmillan and Co., London.

Rajan, R., Zingales, L., 1998. Financial dependence and growth. The American Economic Review 88, 559-586.

Rauch, J., 1991. Modelling the informal sector formally. Journal of of Development Economics 35, 33-47.

Romer, P., 1990. Endogenous Technological Change. Journal of Political Economy XCVIII, 71-102.

Saint-Paul, G., 2002. Employment protection, international specialization, and innovation. European Economic Review 46, 375-395.

Salop, S., 1977. The Noisy Monopolist: Imperfect Information, Price Dispersion, and Price Discrimination. Review of Economic Studies XLIV, 393-406.

Scherer, F., 1967. Market Structure and the Employment of Scientists and Engineers. The American Economic Review LVII, 524-531.

Schumpeter, J., 1942. Capitalism, Socialism and Democracy, Harper and Row, New York. 
Stigler, G., 1971. The Theory of Economic Regulation. Bell Journal of Economics and Management Science II, 3-21.

Stiglitz, J., Weiss, A., 1981. Credit rationing in markets with imperfect information. The American Economic Review 71, 393-410. 
Table 1 Variables acronyms, description and expected impact on innovation

\begin{tabular}{|c|c|c|}
\hline Variable & Description & $\begin{array}{l}\text { Expected } \\
\text { Impact }\end{array}$ \\
\hline Innov & $\begin{array}{l}\text { Dependent variable: proportion of innovative enterprises in industry } \\
i \text {, of country j. 2-digit level of NACE classification, 2004. Source: CIS4, } \\
\text { Eurostat. }\end{array}$ & \\
\hline ERegul & $\begin{array}{l}\text { Economic regulation index, measuring economic policies and } \\
\text { regulations that block competition; values vary between } 0 \text { and } 6 \text { from } \\
\text { least to most restrictive competition, 2003. Source: Product Market } \\
\text { Regulation Indicators Database, OECD. }{ }^{4}\end{array}$ & $+/-$ \\
\hline ARegul & $\begin{array}{l}\text { Administrative regulation index, measuring administrative barriers to } \\
\text { business such as procedures, communication opacity; values vary } \\
\text { between } 0 \text { and } 6 \text { from least to most restrictive competition, } 2003 \text {. } \\
\text { Source: Product Market Regulation Indicators Database, OECD. }\end{array}$ & $+/-$ \\
\hline Entry & $\begin{array}{l}\text { Ratio of the cost of completing the procedures that are officially } \\
\text { required to start and operate a new business to the country's GDP per } \\
\text { capita, 2003. Source: Doing Business Database, The World Bank } \\
\text { Group. }\end{array}$ & $+/-$ \\
\hline Employment & $\begin{array}{l}\text { Rigidity of employment index, measuring the difficulty of employers } \\
\text { to hiring and firing. Higher values of the index mean more protection, } \\
\text { 2003. Source: Doing Business Database, The World Bank Group. }{ }^{6}\end{array}$ & - \\
\hline Law & $\begin{array}{l}\text { Indicator of the efficiency of the legal and judicial system in resolving } \\
\text { legal disputes and protection of property rights. Actual scores range } \\
\text { from approximately }-2.5 \text { to } 2.5 \text {, with higher scores corresponding to } \\
\text { better outcomes, } 2003 \text {. Source: Governance Indicators Database, The } \\
\text { World Bank Group. }\end{array}$ & + \\
\hline Credit & $\begin{array}{l}\text { Credit information index measures rules affecting the scope, } \\
\text { accessibility and quality of credit information available through either } \\
\text { public or private credit registries. The index ranges from } 0 \text { to } 6 \text {, with } \\
\text { higher values indicating the availability of more credit information, } \\
\text { 2003. Source: Doing Business Database, The World Bank Group. }\end{array}$ & + \\
\hline$G D P$ & $\begin{array}{l}\text { Logarithm of gross domestic product per capita, constant prices } \\
\text { average 2001-2003. Source: National Accounts Database, OECD. }\end{array}$ & + \\
\hline Patent & $\begin{array}{l}\text { Growth rate in triadic patent families over the period 1991-2000 of } \\
\text { country } j \text {. Source: Patent and R\&D Databases, OECD. }\end{array}$ & + \\
\hline$R \mathcal{E D}$ & $\begin{array}{l}\text { Logarithm of total expenditure in R\&D on industry i, country j, } 2004 . \\
\text { Source: CIS4, Eurostat. }\end{array}$ & + \\
\hline
\end{tabular}

4 See Conway et al. (2005) for detailed description on the construction of the $E R$ and $A R$ indicators.

${ }^{5}$ See Djankov et al. (2002) for detailed description on the construction of indicator.

${ }^{6}$ See Botero et al. (2004) for detailed description on the construction of indicator.

${ }^{7}$ See Kaufmann et al. (2003) for detailed description on the construction of indicator. 
Expected

Variable

Description

Impact

Logarithm of total turnover in industry $i, 2002$. Source: CIS4, Eurostat.

$+/-$ 
Table 2 Descriptive statistics of dependent and explanatory variables

\begin{tabular}{lllll}
\hline Variable & Min & Max & Mean & Std. Dev. \\
\hline Part I Summary statistics & & & & \\
Innov & 0 & 1 & 0.522 & 0.186 \\
ERegul & 1.377 & 2.563 & 1.898 & 0.356 \\
ARegul & 0.821 & 1.965 & 1.563 & 0.363 \\
Entry & 0 & 36.7 & 9.219 & 10.170 \\
Employment & 10 & 56 & 46.315 & 10.142 \\
Law & 0.744 & 1.985 & 1.513 & 0.409 \\
Credit & 3 & 6 & 4.834 & 1.045 \\
GDP per capita & 2.407 & 3.871 & 3.070 & 0.323 \\
Patent & 0.193 & 0.717 & 0.405 & 0.136 \\
RED & 2.689 & 7.398 & 5.240 & 0.821 \\
Size & 1.579 & 3.749 & 2.310 & 0.261 \\
Scale intensive & 0 & 1 & 0.242 & 0.429 \\
Science based & 0 & 1 & 0.125 & 0.331 \\
Specialized suppliers & 0 & 1 & 0.148 & 0.356 \\
Suppliers dominated & 0 & 1 & 0.197 & 0.398 \\
\hline
\end{tabular}

Part II: Correlation coefficients among selected variables

\begin{tabular}{lllllll} 
& GDP & ERegul & ARegul & Entry & Employment Law \\
ERegul & -0.6687 & & & & & \\
ARegul & -0.5214 & 0.4381 & & & & \\
Entry & -0.7233 & 0.4940 & 0.6209 & & & \\
Employment & -0.6426 & 0.6967 & 0.6193 & 0.4442 & & \\
Law & 0.7743 & -0.8258 & -0.5150 & -0.8322 & -0.4815 & \\
Credit & 0.1174 & -0.1720 & 0.0156 & -0.2561 & -0.2479 & 0.1668 \\
\hline
\end{tabular}


Table 3 Regression results for the relationship between innovation and institutions

\begin{tabular}{|c|c|c|c|}
\hline Variables & (1) & (2) & (3) \\
\hline ERegul & $2.359^{* * *}(0.804)$ & $3.107^{* * *}(1.044)$ & $2.953^{* * *}(0.901)$ \\
\hline ARegul & $0.953^{* \star *}(0.241)$ & $1.380^{\star \star *}(0.286)$ & $1.639^{* * *}(0.401)$ \\
\hline Entry & $0.030^{* *}(0.015)$ & $0.029(0.019)$ & 0.009 (0.017) \\
\hline Employment & $-1.886^{* * *}(0.384)$ & $-1.787^{* * *}(0.323)$ & $-1.903^{* * *}(0.296)$ \\
\hline Law & $1.180^{* *}(0.602)$ & $1.290 *(0.693)$ & $1.111^{*}(0.623)$ \\
\hline Credit & $-0.040(0.030)$ & $-0.041(0.031)$ & $-0.052 *(0.029)$ \\
\hline Scale intensive & & $0.110^{* *}(0.052)$ & $0.942(0.894)$ \\
\hline Science based & & $0.529^{* * *}(0.097)$ & $-3.876(4.491)$ \\
\hline Specialized suppliers & & $0.343^{* * *}(0.076)$ & $-2.841(1.729)$ \\
\hline ERegul $x$ Scale intensive & & & $-0.211(0.168)$ \\
\hline ERegul $x$ Science based & & & $1.076(1.024)$ \\
\hline ERegul $x$ Specialized suppliers & & & $0.937^{* *}(0.405)$ \\
\hline ARegul $x$ Scale intensive & & & $-0.395(0.353)$ \\
\hline ARegul $x$ Science based & & & $0.388(0.757)$ \\
\hline AR $x$ Specialized suppliers & & & $-0.371(0.335)$ \\
\hline Entry $x$ Scale intensive & & & $0.020^{\star *}(0.007)$ \\
\hline Entry $x$ Science based & & & $0.037^{* *}(0.017)$ \\
\hline Entry $x$ Specialized suppliers & & & $0.046^{* * *}(0.012)$ \\
\hline Law $x$ Science based & & & $0.919(0.936)$ \\
\hline Law $x$ Specialized suppliers & & & $1.051^{* *}(0.454)$ \\
\hline Employment $x$ Science based & & & $0.830^{*}(0.482)$ \\
\hline Employment $x$ Specialized suppliers & & & $0.381(0.245)$ \\
\hline Credit $x$ Science based & & & $-0.116^{* * *}(0.028)$ \\
\hline Credit $x$ Specialized suppliers & & & $-0.049(0.031)$ \\
\hline GDP per capita & $0.829^{* * *}(0.308)$ & $1.367^{* * *}(0.387)$ & $1.211^{* * *}(0.311)$ \\
\hline Patents & $5.032^{* * *}(1.018)$ & $6.127^{* * *}(1.274)$ & $6.032^{* * *}(1.020)$ \\
\hline Size & $-0.050(0.189)$ & $-0.197^{*}(0.119)$ & $-0.280^{* * *}(0.087)$ \\
\hline$R \mathcal{E} D$ & $0.169^{* * *}(0.063)$ & $-0.045(0.065)$ & $0.060(0.058)$ \\
\hline Number of observations & 168 & 168 & 168 \\
\hline Log-Pseudolikelihood & -1095.145 & -1034.540 & -992.344 \\
\hline AIC & 13.168 & 12.482 & 12.158 \\
\hline
\end{tabular}

Notes: Dependent variable: ratio of innovative firms to total number of firms of industry $i$, country j, 2004. Manufacturing industries are identified at 2-digit level of NACE classification. All regressions include intercept. Robust standard errors are in parentheses. Based on them ***, **, * mean coefficients statistically significant at $1 \%, 5 \%$, and $10 \%$ level, respectively. See Table 2 for the exact definition of the variables. 